\title{
Associations of risk factors with somatic cell count in bulk tank milk on organic and conventional dairy farms in the United States
}

\author{
K. M. Cicconi-Hogan, ${ }^{* 1}$ M. Gamroth, $†$ R. Richert,‡ P. L. Ruegg, $¥$ K. E. Stiglbauer, $†$ and Y. H. Schukken* \\ ${ }^{*}$ Department of Population Medicine and Diagnostic Sciences, Cornell College of Veterinary Medicine, Cornell University, Ithaca, NY 14853 \\ †Department of Animal Sciences, Oregon State University, Corvallis 97331 \\ ‡Department of Dairy Science, University of Wisconsin-Madison, Madison 53706
}

\section{ABSTRACT}

In the past decade, the demand for organic agricultural products has increased rapidly in the United States and worldwide. Milk quality research is of major interest to both consumers and dairy farmers alike. However, scientific data on milk quality, herd management methods, and animal welfare on organic farms in the United States has been lacking before the research from this study. The objective of this study was to evaluate the association of bulk tank milk somatic cell count (SCC) with management characteristics on organic and conventional dairy farms in New York, Oregon, and Wisconsin. Data from similarly sized organic farms $(\mathrm{n}=192)$, conventional nongrazing farms ( $\mathrm{n}=$ $64)$, and conventional grazing farms $(\mathrm{n}=36)$ were collected at a single farm visit. Of the 292 farms visited, 290 bulk tank milk samples were collected. Overall, no difference in SCC was observed between the conventional and organic grazing systems. Two models were created to assess the effects of various management and herd characteristics on the logarithmic transformation of the SCC (LSCC), one using data from all herds and one using data from organic herds only. From the total herd model, more grain fed per cow per day was negatively associated with LSCC, whereas a positive bulk tank culture for Staphylococcus aureus and years that a farmer reported being in the dairy business were both positively associated with LSCC. In the organic herd model, a seasonal effect indicated that LSCC tended to increase in the summer and decrease in the winter. Grain fed per cow per day, the use of anionic salts in transition-cow diets, the use of gloves during milking, and regular use of a quarantine unit at milking were all negatively associated with LSCC. Similar to the total herd model, a Staph. aureus-positive bulk tank culture was positively associated with LSCC in the organic model. Standard plate count was also positively associated with LSCC in the organic model. Several variables

Received October 15, 2012.

Accepted February 12, 2013.

${ }^{1}$ Corresponding author: kmc277@cornell.edu that were associated with management using external resources were combined to create an external input score. In the total herd model, use of more external resources was negatively associated with LSCC. Conventional herds in the study tended to use more outside management resources than organic herds.

Key words: dairy, somatic cell count association, management, organic

\section{INTRODUCTION}

Udder health is an essential component of quality milk production and cow well-being. Mastitis is the most costly and common disease found in dairy herds in the United States. Clinical mastitis is often responsible for a decrease in milk production and milk discard due to low quality and a rare risk of antimicrobial residues from treatment (van Schaik et al., 2002). Subclinical mastitis results in a lower milk production and reduced milk quality due to increased SCC in milk (Roesch et al., 2007). Determining bulk milk SCC is an internationally recognized method to determine the quality of the milk and the udder health status of the cattle in the herd. Many management practices have been associated with an increased disease risk and with subsequent higher bulk milk SCC (BMSCC; Dohoo, 1982; Barkema et al., 1998; Schukken et al., 2003).

Interest in quality food production, animal welfare, and environmental sustainability has increased in recent years. This holds true for the dairy industry across both organic and conventional dairy production systems. A large body of literature reports associations between management of dairy farms and animal health, as well as milk quality (Zwald et al., 2004; Pol and Ruegg, 2007; Dufour et al., 2011). Consumers have become increasingly curious about the source of their food, and many have become interested in organic or local food sources (Yiridoe et al., 2005). The associated increase in certified organic dairy animals and production of organic dairy products is a direct result of consumers' interest in animal welfare and the environmental impact of conventional dairy farming (Sundrum, 2001). However, there is a lack scientific data on management 
methods and herd health on organic farms to determine the effect of these methods on animal well-being.

Organic management often places an emphasis on preventative measures such as vaccination to control disease (Ruegg, 2009). On organic dairy farms in the United States, animals or products from animals given substances prohibited by the National Organic Program may not be sold as organic, and these animals must be removed from the herd following treatment. However, producers are prohibited from withholding necessary treatment from a sick or injured animal (USDA AMS, 2007). From 2000 to 2008, the number of certified organic cows in the United States increased from 38,196 to 249,766 (USDA ERS, 2008). Due to the recent surge in the number of organic dairy animals, the need for established best management practices and overall herd health information on organic dairy farms is growing, but the industry currently lacks sufficient scientific information to define best organic management practices. Antimicrobial use and mastitis management have been compared between organic and conventional dairy operations in several US studies (Zwald et al., 2004; Pol and Ruegg, 2007; Ruegg, 2009), but few studies have included conventional herds matched on size and location to organic herds. Recent publications from our project have described management on organic and conventional farms (Stiglbauer et al., 2013), as well as the use and role of veterinarians within the same population (Richert et al., in press). A perception exists among consumers that organically produced milk is healthier or of better quality (Yiridoe et al., 2005). However, previous research has found little difference in SCC between organic and conventional dairy farms (Rosati and Aumaitre, 2004; Zwald et al., 2004; Sato et al., 2005) and a review of published literature on organic products lacked any strong evidence for a nutritional advantage of organic foods (Smith-Spangler et al., 2012).

The objective of this study was to evaluate the relationship between management practices and BMSCC for all herds involved in the study and specifically for the subset of organic herds. The aim was to identify a set of management variables for the overall dairy community, as well as specifically to the organic community, that are associated with a lower BMSCC and can be used to define best management practices for conventional as well as organic dairy farms.

\section{MATERIALS AND METHODS}

\section{Recruitment and Herd Selection}

Herd inclusion and recruitment criteria are as described by Stiglbauer et al. (2013) and Richert et al. (in press). Briefly, 292 dairy herds were visited in New York (NY), Oregon (OR), and Wisconsin (WI) between March 2009 and May 2011. A total of 192 organic (ORG) herds and 100 conventional (CON) herds were frequency matched based on herd size and location. In NY, 72 ORG and 25 CON farms were visited; in WI, 96 ORG and $51 \mathrm{CON}$ farms were visited; and in OR, 24 of each ORG and CON farms were visited. Organic herds were initially identified by listings from certifying organizations, county extension agents, and personal contacts. Conventional herds were identified by compiling a list of licensed dairy farms from each state's department of agriculture. Nonresponders received multiple mailings to increase participation. To be eligible for the study, ORG herds were required to have a minimum of 20 adult cows and had been shipping certified organic milk for at least $2 \mathrm{yr}$. Conventional herds were required to have a minimum of 20 adult cows and must have been shipping milk for at least $2 \mathrm{yr}$.

\section{Questionnaire and Data Collection}

The study questionnaire was adapted from previously published survey instruments with input from veterinarians familiar with the dairy industry (Zwald et al., 2004; Pol and Ruegg, 2007; available at http:// milkquality.wisc.edu/organic-dairies/project-cow/). It was reviewed by professional survey developers, and pretested with organic and conventional dairy farmers in each state. Farmers were asked to refer to all available records to ensure accuracy of answers. Recall was frequently limited to the 12 mo before the herd visit or less. Questionnaire information addressed questions under each of the following themes: animal health and personnel, herd inventory and expansion, milk production, breeding and reproductive information, housing, feed and water systems, milking and other routine procedures, disease definitions and treatment, mastitis, management of Johne's disease, veterinarian involvement, calf and heifer information, and DHIA information (if applicable).

Data-collection methods were consistent across the 3 states, as described by Richert et al. (in press). In brief, a single member of the study team conducted all interviews in each state. All investigators met and were trained on administration of the survey and scoring methods used in the study. Throughout the data-collection period, monthly conference calls were held to discuss questions and help ensure standardization of data collection among states. In most herds, the individual directly responsible for animal care was interviewed.

Body condition scoring, udder hygiene, and hock scoring was done by the interviewer on all farms. Scoring on 
farms with more than 50 adult cows was assessed for a minimum of 50 lactating and 20 dry cows, or $20 \%$ of each group, whichever was larger. All adult cows were scored from herds with less than 50 cows. Body condition was evaluated using an accepted scoring method with provided guidelines for examining the thurl line, hooks, pins, and sacral and tailhead ligaments (Ferguson et al., 1994; Elanco Animal Health, 1997). Udder hygiene was assessed on a 4-point system (Schreiner and Ruegg, 2003). Hock scores were assessed using a 3 -point system developed by Cornell University (Ithaca, NY) in 2007 (http://www.ansci.cornell.edu/prodairy/ pdf/hockscore.pdf; accessed September 2012). All scoring forms can be found at http://milkquality.wisc. edu/wp-content/uploads/2011/10/Reference-Guidesfor-Scoring.pdf.

\section{Bulk Tank Milk Sample Collection and Testing}

Samples of bulk milk were collected by study personnel at 290 of the study farms and sent to Quality Milk Production Services at Cornell University for analysis. All samples were taken directly from the bulk tank with a sterile sampler after a minimum of 5 min of agitation, immediately put on ice, and transported to the testing facilities. Two farmers in the study requested that their bulk tank milk not be analyzed and were, therefore, not included in the analyses for this manuscript.

The samples were analyzed using real-time PCR for foodborne pathogens Salmonella spp. (detecting the presence of the invA gene; Nam et al., 2005), Listeria monocytogenes (detecting the hly gene; Jothikumar et al., 2003), and Shiga toxin-producing Escherichia coli (detecting for the presence of the stx1 or stx2 genes; Reischl et al., 2002; Manning et al., 2007). Samples were also tested for Mycoplasma bovis (Hogan et al., 1999); bovine viral diarrhea virus (Renshaw et al., 2000); a modified mastitis bacteria count, inclusive of many contagious and environmental mastitis pathogens (Hogan et al., 1999); and antibodies to Mycobacterium avium subspecies paratuberculosis (Johne's disease; (Paracheck; Prionics AG, Zurich, Switzerland). Samples were couriered to Dairy One Cooperative (Ithaca, NY) and tested for SCC, SPC, laboratory-pasteurized (LP) count, coliform and E. coli count, and butterfat and protein percentages (Wehr and Frank, 2004).

\section{Statistical Analysis}

Study Variables. All statistical analysis was performed using SAS version 9.2 (SAS Institute, 2008). Descriptive analysis of bulk tank milk was performed using PROC UNIVARIATE for BMSCC $(\times 1,000$ cells/ $\mathrm{mL}), \mathrm{SPC}(\times 1,000 \mathrm{cfu} / \mathrm{mL}), \mathrm{LP}$ count $(\times 100 \mathrm{cfu} /$
$\mathrm{mL}$ ), protein (\%), butterfat (\%), coliform count (cfu/ $\mathrm{mL}$ ), and E. coli ( $\mathrm{cfu} / \mathrm{mL})$. The presence of foodborne pathogens Staphylococcus aureus and Streptococcus agalactiae were also included in the analysis. Somatic cell count and SPC were transformed into $\log _{10}$ values of the number of cells per milliliter and $\log _{10}$ values of the number of colony-forming units per milliliter, respectively, and reported as geometric means using the antilog to back-transform the parameters. Due to the large number of negative results, LP count and $E$. coli were dichotomized. The descriptive analysis of LP count and $E$. coli reports the percentage of each grazing system with a positive result (Table 1).

Dairy production system (ORG and CON) and grazing information were combined to create a new predictor variable, grazing system, which had 3 levels: (1) organic, which therefore required grazing (ORG); (2) conventional grazing (CON-GR); and (3) conventional nongrazing (CON-NG). Grazing was defined as herds where $\geq 30 \%$ of DMI of lactating cows were obtained from pasture during the grazing season. Grazing system, herd size category (0-99 cows, 100-199 cows, or $\geq 200$ cows), and site (NY, OR, or WI) were associated with the design of the study and were forced into the modeling process.

Predictor variables considered for inclusion in the SCC model were selected based on similarity to variables described in the meta-analysis of Dufour et al. (2011) and were then separated into the following groups: (1) general farm information, (2) management information, (3) milking procedures, and (4) nutrition. The variables considered within each group were as follows: (1) general farm information: average reported BMSCC (mean of BMSCC from 3 mo before herd visit from on-farm records), average age of primary adult housing in years, percentage of first-lactation cows on the farm, mean lactation number, number of years the farmer had been in the dairy industry, seasonality of herd visit computed using the formulas $\sin [2 \pi \times$ (day of year/365)] and $\cos [2 \pi \times($ day of year/365)], where $\pi$ $=3.14\}$, percentage of problem breeders in the past 12 mo (defined as animals that had been removed due to their failure to conceive, animals that had been removed from the breeding population by being labeled "do not breed" because of failure to conceive, or animals that were 9 month postpartum and not yet pregnant), estimated calving interval in days (provided by herd record systems or calculated by adding $60 \mathrm{~d}$ to the estimated lactation length), amount of milk produced per cow per day $(\mathrm{kg})$, type of milking facility (pit parlor, flat or walkthrough parlor, tiestall or stanchion, or other type of facility), presence of Staph. aureus (yes or no), presence of Strep. agalactiae (yes or no), mean BCS, mean hock score, mean udder hygiene score, and average 
Table 1. Descriptive analysis of milk quality variables from bulk tank samples collected from dairy farms in New York, Oregon, and Wisconsin from March 2009 to May 2011, analyzed among grazing systems ${ }^{1}$

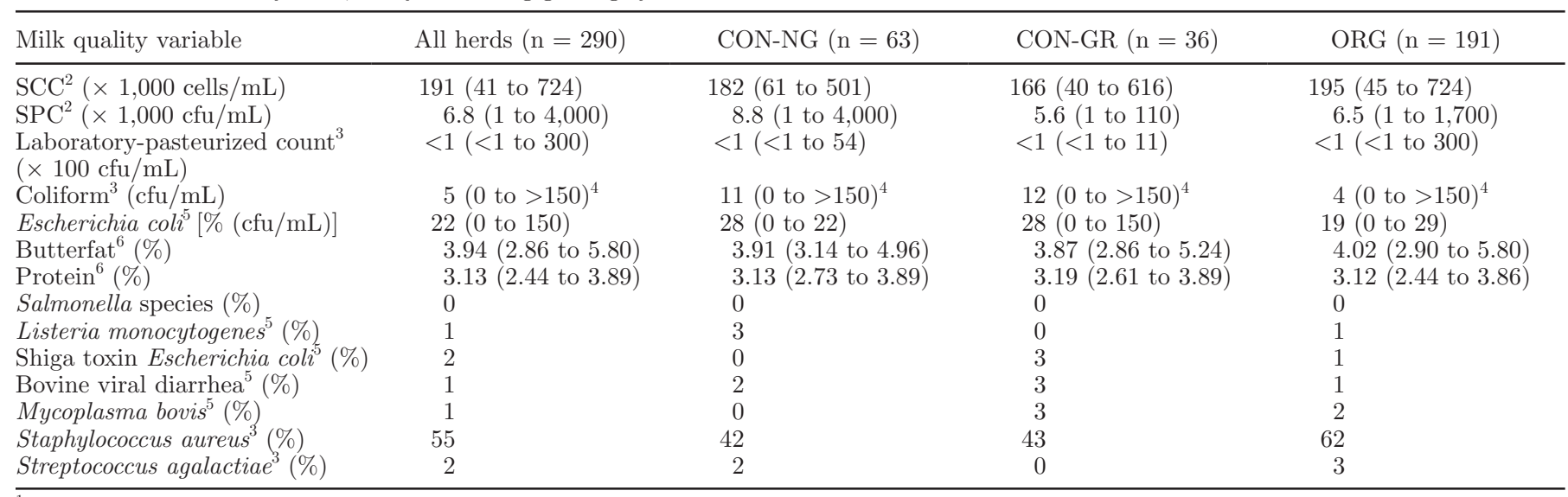

${ }^{1}$ All analyses were based on a single sampling event from each herd. CON-NG = conventional nongrazing; CON-GR = conventional grazing; $\mathrm{ORG}=$ organic

${ }^{2}$ Geometric mean and range reported.

${ }^{3}$ Analyzed variable had nonnormal distribution (median and range reported).

${ }^{4}$ Testing was done on Petrifilm plates (3M, St. Paul, MN), which had an upper limit of $150 \mathrm{cfu} / \mathrm{mL}$.

${ }^{5}$ Percentages of each group that tested positive. Ranges presented in parentheses are in colony-forming units per milliliter for nonbinary variables. Escherichia coli counts are represented as positive results ( $\geq 1 \mathrm{cfu} / \mathrm{mL})$.

${ }^{6}$ Range represented in parentheses is in percentage.

reported SPC (mean of SPC from 3 mo prior to herd visit from on-farm records: $<1-7,000,8,000-32,000$, or $\geq 33,000 \mathrm{cfu} / \mathrm{mL}$ ); (2) management information: use of natural service for nonlactating heifers (none, some, or all), use of natural service for adult cows (none, some, or all), use of DHIA (yes or no), use of a dedicated calving area separate from all other cows (yes or no), farmer-reported improved laneways (yes or no), use of a segregation unit or bucket milker during milking (yes or no), clinical mastitis culturing (performed regularly, performed infrequently, or not ever performed), number of people who treat mastitis, written herd health and treatment records (yes or no), regular veterinarian visits (yes or no), use of vaccinations in adult cows (yes or no), use of a nutritionist (yes or no), use of anionic salts in transition-cow diets (yes or no), frequency of bulk tank cultures taken per year (never, monthly, quarterly, or other times per year), use of a blanket dry treatment (categorized as a blanket antimicrobial, internal or external sealant for all cows, combination of antibiotic and sealant for all cows, other blanket treatment, or no blanket treatment), routinely checking postpartum cows (yes or no), use of a California mastitis test (yes or no), keeping sick and healthy cows separate (yes or no), use of a separate location to transfer cows (yes or no), introduction of new dairy cows or heifers in the past 12 mo (yes or no), percentage of herd with 3 or fewer teats, and the percentage of the herd that had at least 1 quarter segregated from the bulk tank; (3) milking procedures: number of times milked per day, premilking teat disinfection (yes or no), postmilking teat disinfection (yes or no), use of gloves during milking (yes or no), use of automatic take offs (yes or no), number of milkers on the farm, forestripping before milking (yes or no), and number of milking units (0-10, $11-19$, or $\geq 20$ ); (4) nutrition: use of grazing (yes or no), use of TMR (yes or no), and amount of grain fed per cow per day $(\mathrm{kg})$. The following variables were specific to the organic model, and not analyzed in the total herd model: number of acres used for pasture, average percentage of DMI from pasture, percentage improved pasture from $7 \mathrm{yr}$ prior to the herd visit, the number of years certified organic, number of days grazing in the last grazing season, and the use of rotational grazing (yes or no).

Use of External Input. To assess the level of external support a farmer was using, several variables were combined to create a new variable, named external input score (EIS). It was additive of the following variables, several of which were changed to binary to allow for a 0 (no) or 1 (yes) scale: use of nutritionist (no or yes), regular use of a veterinarian (no or yes), use of DHIA (no or yes), use of anionic salts in transition-cow diets (no or yes), vaccination of cows (no or yes), vaccination of calves (no or yes), regular pregnancy checks (no or yes), a written record of herd health events (no or yes), any use of AI in nonlactating heifers (no or yes), and any use of AI in lactating cows (no or yes). The resulting additive scale ranged from 0 to 10. Because of the statistical and logical correlation 
of these variables to one another, the EIS was used in the modeling process in replacement of the individual variables that remained in the final models before the backward stepwise process.

Statistical Models. We analyzed data from 290 of the 292 farms included in the study due to missing bulk tank information from 2 OR farms. The primary outcome variable was the BMSCC on the day of the herd visit. Due to the heavily right skewed distribution of the BMSCC variable, it was logarithm transformed to the $\log _{10}$ of the number of cells per milliliter before model construction (LSCC). PROC UNIVARIATE was used to analyze individual continuous variables and assess normality of the variable distributions. Variables with a nonnormal distribution were categorized into 3 groups based on the 25th and 75th percentiles (0-25, $26-75$, or $76-100 \%$ ).

Two linear regression models were constructed to determine the relationship between LSCC and the individual predictor variables using different subsets of data: (1) a model constructed using data from all herds in the study, hereinafter referred to as the total herd model and (2) a model constructed using data from all ORG herds in the study, hereinafter referred to as the organic herd model. Variable selection was done according to the method described by Dohoo et al. (2010).

The general form of the linear model used for the total herd model was as follows:

$$
\begin{gathered}
\text { LSCC }=\beta_{0}+\beta_{1} \text { grazing system }+\beta_{2} \text { herd size } \\
\text { category }+\beta_{3} \text { site }+\beta_{\kappa} X_{k}+\ldots+\varepsilon,
\end{gathered}
$$

where $\beta_{0}=$ intercept term, $\beta_{\mathrm{i}}=$ regression coefficient, $\mathrm{X}_{\mathrm{k}}=$ predictor variable, and $\varepsilon=$ error term.

Model selection was performed in 3 steps. First, each individual predictor variable was screened for unconditional associations with LSCC by linear regression using PROC MIXED. Then, unconditionally associated variables from each of the 4 groups of predictor variables (general dairy information, management, nutrition, and milking procedures), in addition to all design variables, were included for selection for 4 multivariable submodels using a $P \leq 0.25$ cutoff. Finally, all predictor variables that remained in the submodels $(P \leq 0.25)$ were selected for a final multivariable regression model, analyzed using PROC GLM. Biologically relevant firstorder interactions were assessed in the final model. The final multivariable model was constructed using backward selection techniques. Predictor variables significant at $P \leq 0.10$ and all design variables remained in the final multivariable model. The model-building process used for the organic herd model was identical to the process used for building the total herd model except that grazing system was not included as a design variable, and grazing-specific variables were included.

\section{RESULTS}

\section{Bulk Tank Results}

The geometric mean SCC of the overall study population was 191,000 cells $/ \mathrm{mL}$, ranging from 41,000 to 725,000 cells $/ \mathrm{mL}$ (Table 1 ). When the back-transform of LSCC was stratified by grazing system, the geometric mean SCC were 182,000, 166,000, and 195,000 cells/ $\mathrm{mL}$ for CON-NG, CON-GR, and ORG farms, respectively (Table 1). The overall geometric mean SPC was $6,800 \mathrm{cfu} / \mathrm{mL}$, and stratified means were 8,800, 5,600, and $6,500 \mathrm{cfu} / \mathrm{mL}$ for CON-NG, CON-GR, and ORG farms, respectively. Total coliform counts among CONNG, CON-GR, and ORG farms had medians of 11, 12 , and $4 \mathrm{cfu} / \mathrm{mL}$, respectively, with an overall median of $5 \mathrm{cfu} / \mathrm{mL}$. Due to the large number of negative results $(0 \mathrm{cfu} / \mathrm{mL})$, the descriptive analysis of LP and $E$. coli variables reports the percentage of each grazing system with a positive result $(\geq 1 \mathrm{cfu} / \mathrm{mL}$; Table 1$)$. Laboratory-pasteurized count results were positive on $45 \%$ of CON-NG farms, 39\% of CON-GR farms, and $34 \%$ of ORG farms, and for $37 \%$ of the total population. Twenty-eight percent of bulk tanks on both CON-NG and CON-GR farms were positive for E. coli, whereas $19 \%$ of ORG farms and $22 \%$ of all herds' milk tested positive. Mean butterfat (\%) on CON-NG, CON-GR, and ORG farms was $3.91,3.87$, and $4.02 \%$, respectively. The mean protein percentages from the bulk tank milk were $3.13,3.19$, and $3.12 \%$ for CON-NG, CON-GR, and $\mathrm{ORG}$, respectively. The prevalence of foodborne pathogen DNA of L. monocytogenes and Shiga toxinproducing E. coli was low (Table 1). Salmonella DNA was not detected in any of the samples. Bovine viral diarrhea virus and $M$. bovis were rare in the bulk milk of the study population, with only $1 \%$ of total samples testing positive for each.

Contagious mastitis pathogens from the bulk tank that were assessed for differences between grazing systems were Staph. aureus and Strep. agalactiae from the modified bacteria count testing. The percentage of ORG bulk tanks with a Staph. aureus-positive culture was $61 \%$, compared with $42 \%$ of CON-NG and $43 \%$ of CON-GR bulk tanks (Table 1), with an overall percentage of $55 \%$. The prevalence of Strep. agalactiae was also low, with only $2 \%$ of bulk tanks testing culture positive for Strep. agalactiae.

\section{Univariate Analysis}

Of the approximately 60 predictor variables analyzed using univariate linear regression analysis, 29 were un- 
conditionally associated $(P<0.25)$ with LSCC and selected for inclusion in the final model. The association of average reported SCC and LSCC were analyzed to ensure accuracy and reassurance of the BMSCC (Figure $\left.1 ; \mathrm{R}^{2}=0.76, P<0.001\right)$, but the average reported SCC variable was not included in the model-building process.

Total Herd Model Building. Differences and associations with LSCC among binary and categorical variables are presented in Table 2. Continuous general farm characteristic variables that were unconditionally associated $(P \leq 0.25)$ with LSCC in the total herd data set were the number of reported years in the dairy business, percentage of first-lactation cows on the farm, and the milk production per cow per day. The cosine and sine of seasonality variables were also associated with LSCC; summer months tended to have an increase in LSCC. The EIS was the only continuous management variable that was unconditionally associated $(P \leq 0.25)$ with decreased LSCC. The number of milkers on the farm was the only continuous milking variable that had an unconditional association with increased LSCC in the total herd data set. The amount of grain fed per cow per day was the only continuous nutritional vari- able that was unconditionally associated with LSCC in the total herd data set.

The predictor variables that were selected for inclusion in the final multivariable LSCC model before backward stepwise regression using a cutoff value of $P$ $\leq 0.25$ were the number of years in the dairy industry, seasonality, presence of Staph. aureus in the bulk tank, average reported SPC, the EIS, the percentage of heifers bred using natural service, the use of gloves, the number of milkers on the farms, the amount of grain fed per cow per day, and the use of anionic salts in transition-cow diets.

Selected Total Herd Model. Backward stepwise linear regression modeling resulted in the final model that, in addition to the forced design variables (grazing system, herd size, and location) included 4 predictor variables (Table 3 ). The variables representing the percentage of heifers on the farm bred using natural service and the use of anionic salts in transition-cow diets were removed from the model, as they were a part of the EIS calculation. The EIS was negatively associated with LSCC $(P=0.008)$, as was amount of grain fed per cow per day $(P=0.036)$. Bulk tank milk samples that tested positive for Staph. aureus typically had a

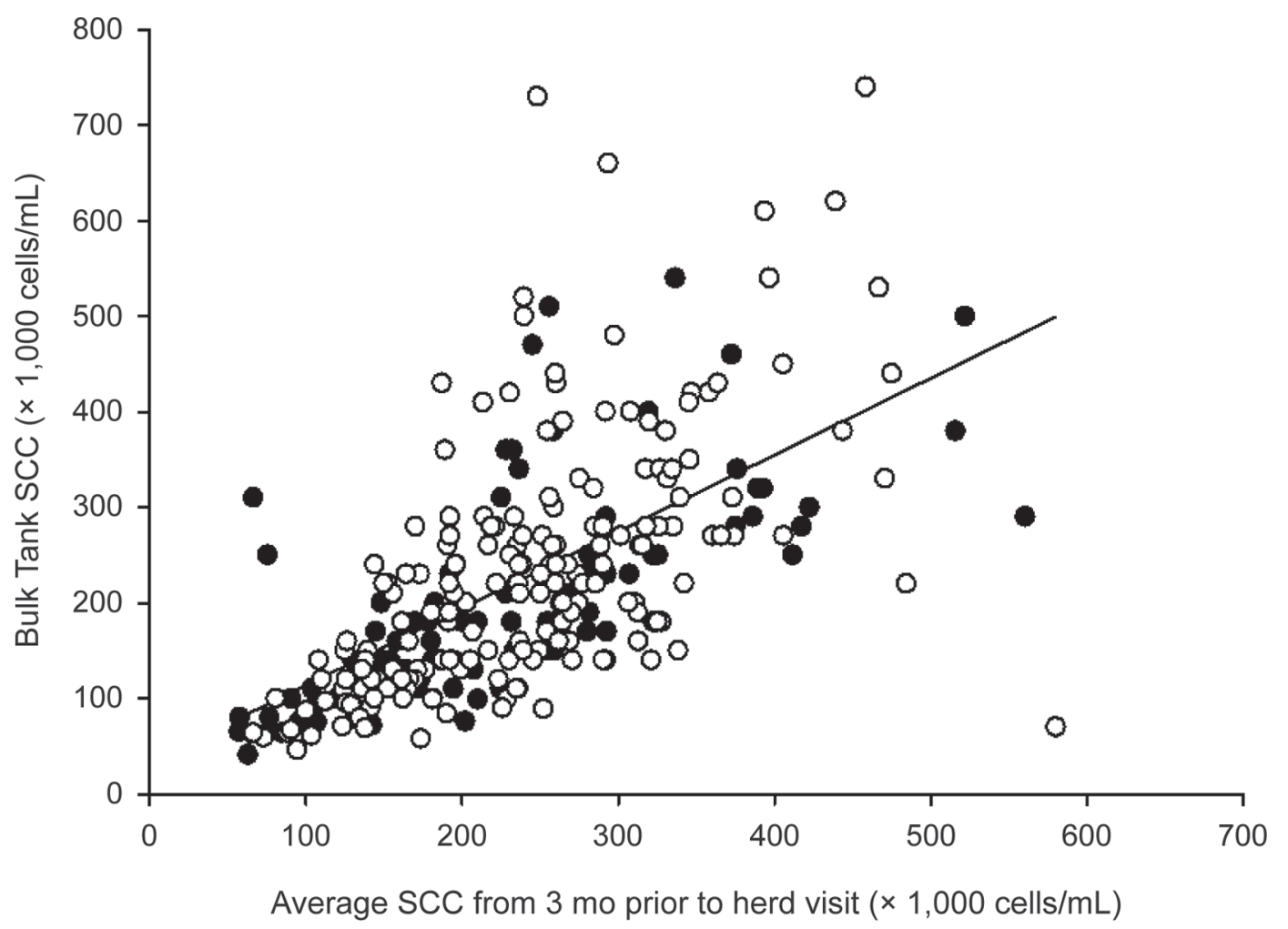

Figure 1. Measured SCC $(\times 1,000$ cells $/ \mathrm{mL})$ from bulk tank milk on the day of collection plotted against the average bulk tank SCC from 3 mo before the collection date from 187 organic (open circles) and 96 conventional (closed circles) farms in New York, Oregon, and Wisconsin. The SCC information was unavailable for 4 organic and 3 conventional farms. Data were collected between March 2009 and May 2011 ; $\mathrm{R}^{2}=$ $0.76, P<0.001$. 
Table 2. Least squares means of the geometric mean of the bulk tank milk of the logarithmic transformation of $\mathrm{SCC}\left(\mathrm{log}_{10}\right.$ cells $\left./ \mathrm{mL}\right)$ among 290 farms in New York, Wisconsin, and Oregon ${ }^{1}$

\begin{tabular}{|c|c|c|c|c|c|}
\hline Variable & Variable level & $\begin{array}{l}\text { No. of } \\
\text { herds }\end{array}$ & $\begin{array}{c}\text { Geometric } \\
\text { mean SCC } \\
(\times 1,000 \\
\text { cells } / \mathrm{mL})\end{array}$ & $\begin{array}{c}95 \% \text { CI } \\
(\times 1,000 \\
\text { cells } / m L)\end{array}$ & $\begin{array}{c}P \text {-value } \\
(P \leq 0.25)\end{array}$ \\
\hline \multirow{3}{*}{ Grazing system $^{2}$} & $\mathrm{CON}-\mathrm{NG}$ & 63 & 182 & $158-209$ & 0.17 \\
\hline & CON-GR & 36 & 166 & $138-200$ & \\
\hline & ORG & 191 & 195 & $182-214$ & \\
\hline \multirow{3}{*}{ Average reported $\mathrm{SPC}^{3}(\mathrm{cfu} / \mathrm{mL})$} & $<1-7,000$ & 97 & 178 & $159-200$ & 0.24 \\
\hline & $8,000-32,000$ & 131 & 200 & $182-219$ & \\
\hline & $\geq 33,000$ & 62 & 200 & $174-229$ & \\
\hline \multirow{2}{*}{ Bulk tank culture - Staphylococcus aureus } & Negative & 131 & 162 & $41-724$ & 0.21 \\
\hline & Positive & 159 & 214 & $63-724$ & \\
\hline \multicolumn{6}{|l|}{ Management } \\
\hline \multirow[t]{3}{*}{ Percentage of adult cows bred by natural service } & $0-25 \%$ & 203 & 174 & $162-191$ & $<0.001$ \\
\hline & $26-75 \%$ & 33 & 224 & $182-269$ & \\
\hline & $76-100 \%$ & 54 & 246 & $209-282$ & \\
\hline \multirow{2}{*}{ Dedicated calving area } & No & 204 & 200 & $182-214$ & 0.092 \\
\hline & Yes & 86 & 174 & $155-200$ & \\
\hline \multirow[t]{2}{*}{ Improved laneways } & No & 133 & 204 & $182-224$ & 0.13 \\
\hline & Yes & 157 & 182 & $166-200$ & \\
\hline \multirow[t]{2}{*}{ Use of segregation unit or bucket milker } & No & 200 & 186 & $182-214$ & 0.069 \\
\hline & Yes & 90 & 174 & $155-195$ & \\
\hline \multirow{2}{*}{ Regular vet visits } & No & 153 & 204 & $186-224$ & 0.039 \\
\hline & Yes & 137 & 178 & $162-195$ & \\
\hline \multirow[t]{2}{*}{ Routine fresh cow checks } & No & 247 & 214 & $178-251$ & 0.20 \\
\hline & Yes & 43 & 186 & $174-200$ & \\
\hline Use of nutritionist & No & 109 & 209 & $186-229$ & 0.044 \\
\hline \multirow[t]{2}{*}{ Gloves } & No & 95 & 209 & $186-234$ & 0.042 \\
\hline & Yes & 195 & 182 & $170-200$ & \\
\hline Use of automatic take-offs & No & 179 & 204 & $186-224$ & 0.015 \\
\hline & Yes & 111 & 174 & $155-191$ & \\
\hline Use of post-dip & No & 24 & 219 & $178-275$ & 0.20 \\
\hline & Yes & 266 & 191 & $178-200$ & \\
\hline Nutrition & & & & & \\
\hline Use of TMR & No & 165 & 200 & $182-219$ & 0.17 \\
\hline & Yes & 125 & 182 & $162-200$ & \\
\hline Use of anionic salts & No & 265 & 195 & $182-209$ & 0.046 \\
\hline & Yes & 25 & 155 & $123-191$ & \\
\hline${\text { Use of } \text { grazing }^{6}}^{6}$ & No & 23 & 166 & $132-209$ & 0.19 \\
\hline & Yes & 267 & 195 & $182-209$ & \\
\hline
\end{tabular}

${ }^{1}$ Variables shown are the categorical and binary general farm characteristics, management, milking, and nutrition and grazing variables analyzed for unconditional association. Models did not include the design variables grazing system, herd size, or location.

${ }^{2} \mathrm{CON}-\mathrm{NG}=$ conventional nongrazing; $\mathrm{CON}-\mathrm{GR}=$ conventional grazing; ORG = organic.

${ }^{3}$ Refers to the mean SPC from 3 mo before the herd visit; obtained from on-farm records.

${ }^{4}$ Combination is representative of antimicrobial with a sealant treatment; sealant dry treatments include internal and external teat sealants [e.g., Orbeseal or T-Hexx (Hydromer Inc., Branchburg, NJ)]; other dry treatments include dry treatment-specific teat dip and alternative treatments.

${ }^{5}$ Refers to any reported vaccine.

${ }^{6}$ Refers to any positive response for use of grazing; not limited to the organic minimum DMI percentage for grazing. 
Table 3. Final total herd linear regression model showing the association of significant $(P \leq 0.1)$ variables and the bulk tank using the logarithmic transformation of SCC $\left(\log _{10}\right.$ cells $\left./ \mathrm{mL}\right)$ among conventional nongrazing $(\mathrm{CON}-\mathrm{NG} ; \mathrm{n}=63)$, conventional grazing $(\mathrm{CON}-\mathrm{GR} ; \mathrm{n}=$ $36)$, and organic (ORG; $\mathrm{n}=191$ ) farms ${ }^{1}$

\begin{tabular}{llcc}
\hline Variable & Level & Estimate & Final model $P$-value \\
\hline Intercept & & 2.192 & 0.059 \\
Grazing system & CON-NG & 0.049 & 0.001 \\
& CON-GR & Reference & 0.086 \\
Location & ORG & 0.098 & 0.093 \\
& NY & Reference & \\
Herd size & WI & 0.055 & 0.099 \\
& OR & Reference & \\
External input score & $\geq 200$ cows & -0.019 & \\
Amount of grain fed (kg/cow per day) & $100-199$ cows & -0.011 & 0.048 \\
Bulk tank culture - Staphylococcus aureus & $20-99$ cows & 0.111 & 0.008 \\
Number of years in the dairy industry & Continuous $(0-10)$ & Continuous & $<0.001$ \\
Trazing system, & Positive & 0.004 & $<0.001$
\end{tabular}

${ }^{1}$ Grazing system, location (New York, Wisconsin, and Oregon), and herd size were always included in the model as design variables. Estimates provided are the $\beta$-coefficient for the given variable.

${ }^{2}$ External input score is a continuous, additive variable from 0 to 10. It consists of the following variables and their scoring schemes: use of nutritionist (no or yes; yes $=1$ ), regular use of a veterinarian (no or yes; yes $=1$ ), use of DHIA (no or yes; yes $=1$ ), use of anionic salts in transition cow diets (no or yes; yes $=1$ ), vaccination of cows (no or yes; yes $=1$ ), vaccination of calves (no or yes; yes $=1$ ), regular pregnancy checks (no or yes; yes $=1$ ), a written record of herd health events (no or yes; yes $=1$ ), any use of AI for nonlactating heifers (no or yes; yes = 1), and any use of AI for lactating cows (no or yes; yes $=1$ ).

higher LSCC $(P<0.001)$. As the number of years that a farmer reported being in the dairy industry increased, the LSCC also increased $(P<0.001)$.

Organic Herd Model Building. Differences and associations with LSCC among binary and categorical variables in the organic herd model are presented in Table 4. In the ORG herd data set, continuous general farm characteristics that were associated with LSCC were the number of years in the dairy business, the number of years a farm has been certified organic, and milk production per cow per day. The cosine of seasonality variable was associated with LSCC, with a peak in the summer months and a low in the winter months of LSCC. The EIS was the only continuous management variable that was unconditionally associated with LSCC in the ORG herd data set. The number of milkers on the farm was unconditionally associated with increased LSCC in the ORG data set. The continuous nutritional variables that were unconditionally associated with LSCC in the ORG herd data set were the average percentage of DMI from pasture and the number of days grazing per year and the amount of grain fed per cow per day.

In the organic herd model, the predictor variables that were selected for inclusion in the final multivariable LSCC model before backward stepwise regression using a cutoff value of $P \leq 0.25$ were the number of years a farmer had spent in the dairy business, the number of years the farm was certified organic, the average SPC, a Staph. aureus-positive result from the bulk tank, the
EIS, the use of a segregation unit or bucket milker at milking, regular visits from the veterinarian, vaccinations of adult cows, the use of gloves, the amount of grain fed per cow per day, the use of rotational grazing, and the use of anionic salts in transition-cow diets.

Selected Organic Herd Model. Backward stepwise linear regression modeling resulted in the final model that contained the 2 required design variables (herd size and location) and 8 other variables (Table 5). An increase in the number of years in the dairy industry was associated with a higher LSCC $(P=0.024)$. A seasonal effect was observed on LSCC $(P=0.066)$, which indicated a peak in the summer months and a depression in the winter months (Figure 2). A Staph. aureus-positive bulk tank culture was associated with a higher LSCC $(P<0.001)$. Farmers that reported use of a segregation unit or bucket milker during milking tended to have a lower LSCC $(P=0.002)$, as did the use of gloves during milking $(P=0.089)$. Feeding more grain per cow per day was associated with a lower LSCC $(P=$ 0.062). Higher average reported SPC from 3 mo before the herd visit was associated with a higher LSCC $(P=$ 0.071). Feeding anionic salts in transition-cow diets was associated with a lower LSCC $(P=0.035)$.

\section{DISCUSSION}

This study was a component of a larger project with an overarching goal to assess the herd health, management practices, and herd characteristics of conventional 
Table 4. Least squares means of the geometric mean of the bulk tank milk of the logarithmic transformation of $\mathrm{SCC}\left(\mathrm{log}_{10}\right.$ cells $\left./ \mathrm{mL}\right)$ among 191 organic farms in New York, Wisconsin, and Oregon ${ }^{1}$

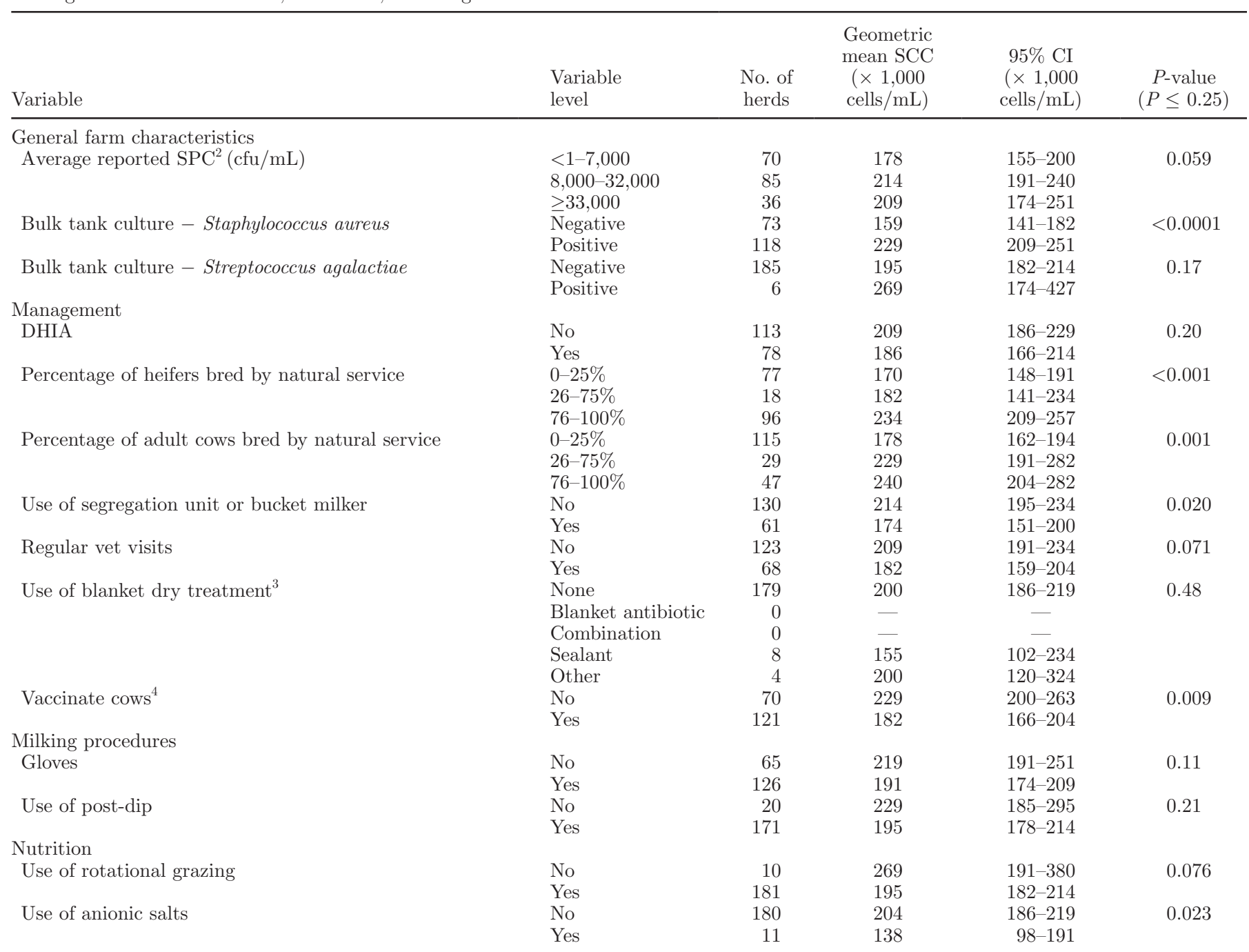

${ }^{1}$ Variables shown are the categorical and binary general farm characteristics, management, milking, and nutrition and grazing variables analyzed for unconditional association. Models did not include the design variables grazing system, herd size, or location.

${ }^{2}$ Refers to the mean SPC from 3 mo before the herd visit; obtained from on-farm records.

${ }^{3}$ Combination is representative of antimicrobial with a sealant treatment; sealant dry treatments include internal and external teat sealants [e.g., Orbeseal or T-Hexx (Hydromer Inc., Branchburg, NJ)]; other dry treatments include dry treatment-specific teat dip and alternative treatments.

${ }^{4}$ Refers to any reported vaccine.

and organic dairy farms in NY, OR, and WI. The purpose of this manuscript is to provide an analysis of the milk quality of bulk tank milk, as well as to determine the effect of selected management variables on BMSCC.

All ORG farms in our study were matched with CON farms of similar size and location, so that comparisons would be as accurate as possible. Also, the wide range of management methods and, subsequently, milk-quality results are represented in our population. Approximately $30 \%$ of the organic population across the 3 states was visited. This study was primarily a cross-sectional study with a longitudinal component and we recognize that several limitations exist with this method of data collection and research. Although the study was strong internally, care should be taken when interpreting the results and applying to a group outside of the study demographic.

Results of this study confirmed previous research, which indicated that grazing system does not affect BMSCC (Stiglbauer et al., 2013). The prevalence of foodborne pathogenic bacteria in our sample of herds was lower than reported in previous studies (Van Kessel et al., 2011). This may be due to the differences in methodology between the 2 studies. The number of 
Table 5. Final organic herd linear regression model showing the association of significant variables $(P \leq 0.1)$ and the bulk tank milk SCC using the logarithmic transformation of SCC $\left(\log _{10}\right.$ cells $\left./ \mathrm{mL}\right)$ of all organic dairies $(\mathrm{n}=191)^{1}$

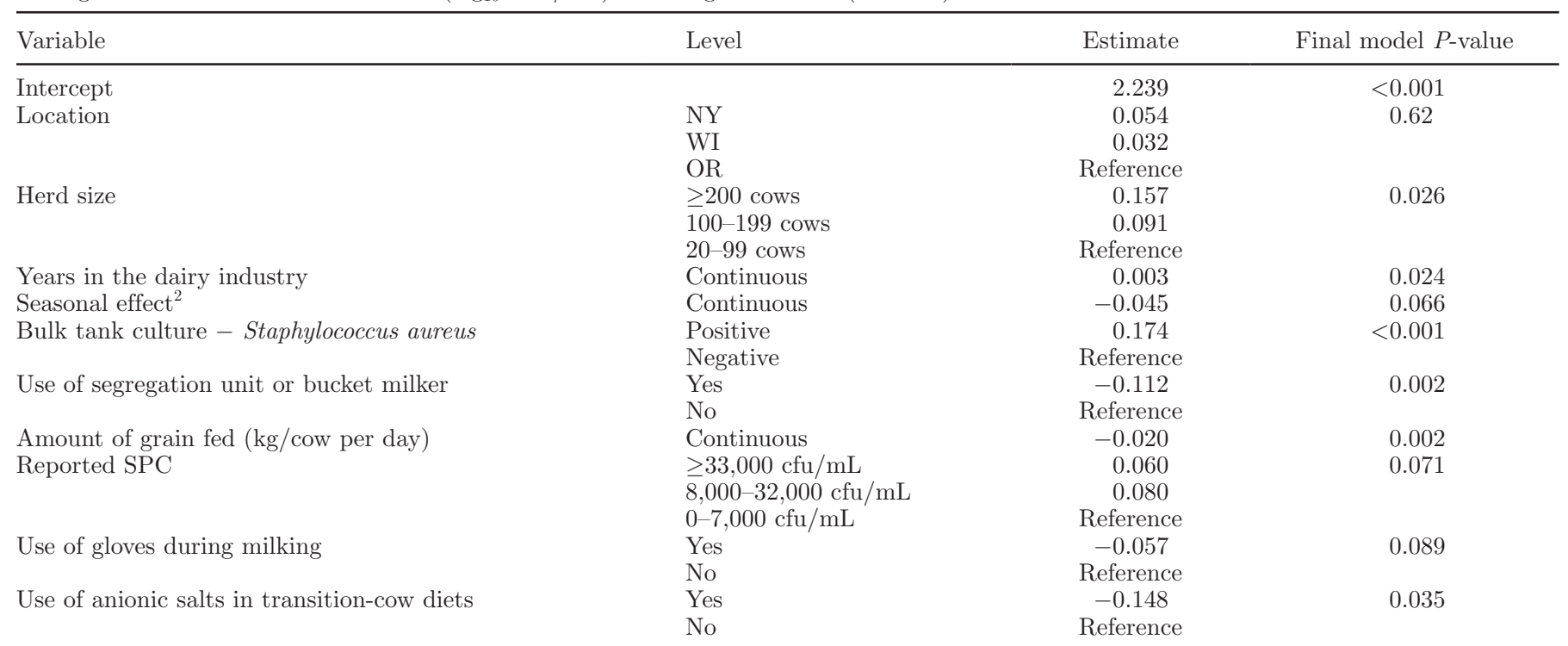

${ }^{1}$ Grazing system, location (New York, Wisconsin, and Oregon), and herd size were always included in the model as design variables. Estimates provided are the $\beta$-coefficient for the given variable.

${ }^{2}$ Seasonal effect was computed using the formulas $\sin [2 \pi \times($ day of year/365) $]$ and $\cos [2 \pi \times($ day of year/365) $]$ where $\pi=3.14$. We are defining it here as a continuous variable.

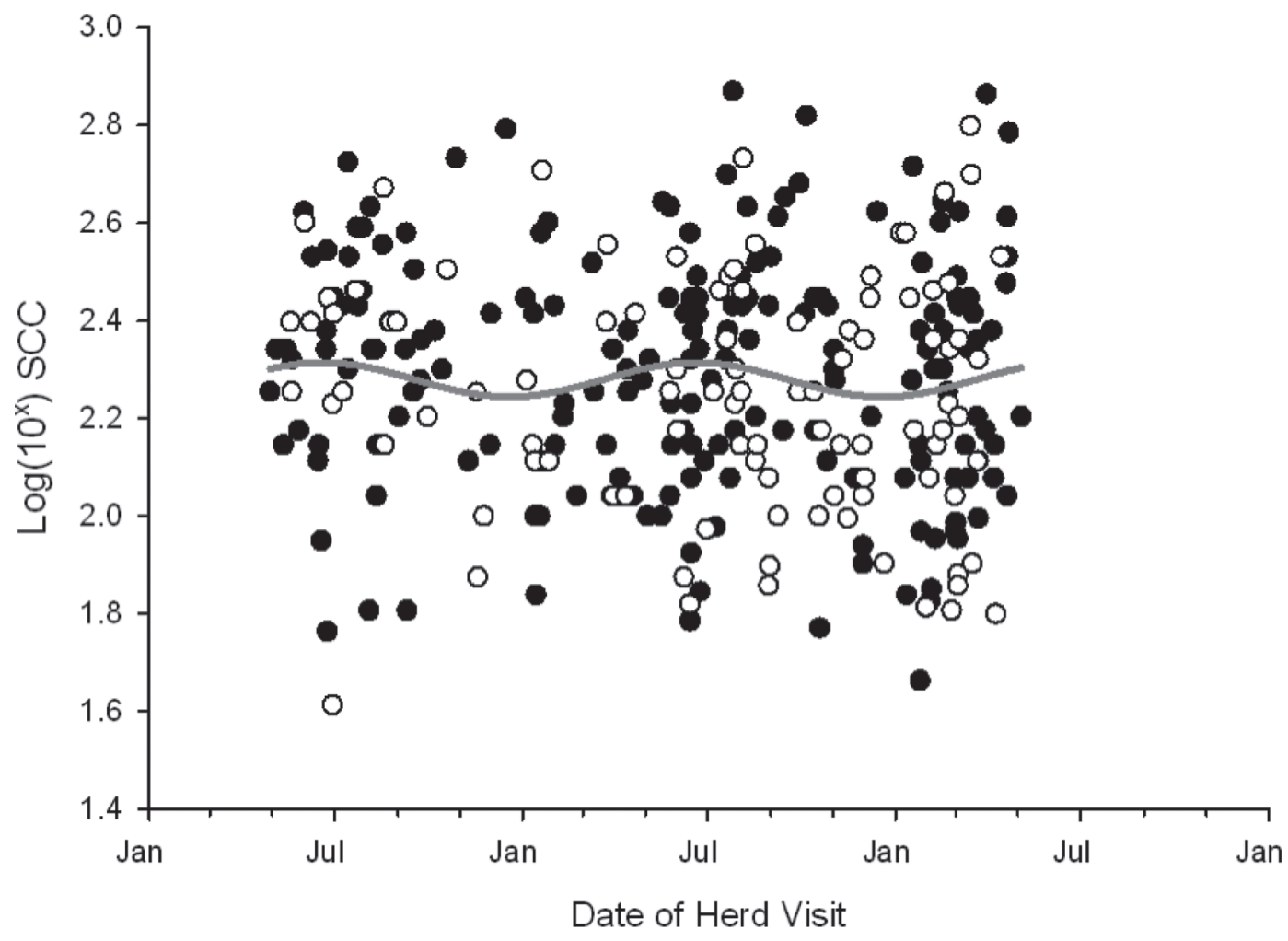

Figure 2. Seasonal trend of the logarithmic transformation of SCC (cells/mL) by dairy production system of 290 farms in New York, Wisconsin, and Oregon. Closed circles represent organic farms $(\mathrm{n}=191)$; open circles represent conventional farms $(\mathrm{n}=99)$. Trend shown (gray line $)$ is the cosine $(P=0.091)$, indicating peaks in SCC in the summer months and depression in the winter months. Dates of herd visits span from March 2009 to May 2011. The logarithmic transformation of the SCC was on the $10^{2}$ form of the variable. 
farms sampled in the 2011 study was much larger than ours and samples were also taken from milk filters, instead of just from the bulk tank. Our study population consisted of primarily small farms ( $\leq 100$ adult cows), whereas samples collected for Van Kessel et al. (2011) came from a wide range of farm sizes. In addition to these differences, it should be noted that only 3 foodborne pathogens were tested for, so the testing was by no means exhaustive. These differences should be kept in mind when interpreting the prevalence of foodborne pathogens.

The presence of Staph. aureus in the bulk tank milk was higher on ORG farms (61\%) than CON-NG (42\%) and CON-GR (43\%) farms, which was not unexpected, as previous research has shown a higher prevalence of Staph. aureus among organic farms (Sato et al., 2004; Pol and Ruegg, 2007). Because Staph. aureus is a contagious pathogen that is difficult to treat, the typical management strategy is to cull the infected animal or, alternatively, milk her last to avoid transmitting the bacteria to the rest of the herd via the milking machinery. The higher prevalence of Staph. aureus on ORG farms may be due to the difficulty in replacing culled animals that are organically certified. It may also be due to the reluctance of ORG farms to bring in adult animals from outside sources (Stiglbauer et al., 2013). Approximately $30 \%$ of our ORG herds used a segregation milking unit or a bucket milker, which was found to be associated with a lower BMSCC. An increased implementation of a bucket milker use by farms that are harboring Staph. aureus cows may be a relatively easy and financially sound method to improve milk quality on organic farms (Wilson et al., 1995). Additionally, we found that $94 \%$ of our ORG herds did not report use of any dry cow treatment. The National Mastitis Council recommends intramammary dry cow treatment of all cows as one of the key steps in an effective mastitis control program. Some IMI caused by Staph. aureus and other gram-positive organisms have been responsive to intramammary treatment, so the lack of dry cow treatment in ORG herds may be the cause of the higher Staph. aureus prevalence (Sol and Sampimon, 1995). However, the cause of a higher prevalence of Staph. aureus on ORG farms is a matter that should be further explored in future research.

The total herd model showed a relationship between grain feeding and decreased LSCC, which may be caused by a dilution effect. Animals that are fed more grain are likely to produce more milk, which may dilute the number of SCC per milliliter in the bulk tank. Previous research has shown that increased production is associated with a slightly decreased SCC (Green et al., 2006), although the strength of this effect is low, as shown by the parameter estimate in our total herd model (Table 3). The presence of Staph. aureus in bulk tank milk and its association with a higher SCC is not unexpected (Barkema et al., 1999; Olde Riekerink et al., 2006), as subclinical mastitis caused by Staph. aureus is associated with increased BMSCC. More years in the dairy industry was associated with a higher BMSCC. This could be interpreted as younger farmers, or farmers that have recently gotten into the industry, being more aggressive in their management and treatments. However, the regression coefficient is quite small, and a change of $10 \mathrm{yr}$ only predicts a BMSCC difference of 15,000 to 30,000 cells $/ \mathrm{mL}$. Research more focused on management reasoning may provide a more complete picture of the relationship between BMSCC and the number of years in the dairy business.

A point of interest is that of the 8 variables from the organic herd model determined to be significant, 3 of the variables were also included in the total herd model. This suggests that although many of the variables that affect milk quality on organic farms are the same as those that are significant in the general dairy population, the organic demographic may use different methods and face different challenges than the conventional population.

Of interest from both models were variables that related to the farmer's use of external management resources. In our previous paper, Stiglbauer et al. (2013), we created a scale that allowed us to assess how much outside support was being used on the farm, and how it related to various management variables. We determined that more use of outside support and management sources was associated with a lower SCC. To understand the use of external resources and their effects on milk quality, we combined the results from the scoring system used in Stiglbauer et al. (2013) with the multiple correspondence analysis results from Richert et al. (in press), which was used to characterize veterinarian use in our study population. The multiple correspondence analysis results indicated that intensive management practices, such as vaccinations, use of AI, and use of a nutritionist were associated with a higher likelihood of veterinarian use. We combined several of the variables from both publications to create a more complete scoring system, referred to as the EIS. This score was designed to help measure how many different outside sources the farmers were using to help manage the farm. Some of the EIS variables by themselves did not have any logical relationship with LSCC, but still presented an association, such as high percentages of bull-bred heifers on the farm. Our EIS was inclusive of many different overarching management decisions and factors, but was by no means exhaustive. Several of the traditional variables typically used to troubleshoot IMI and the resulting high BMSCC were not signifi- 


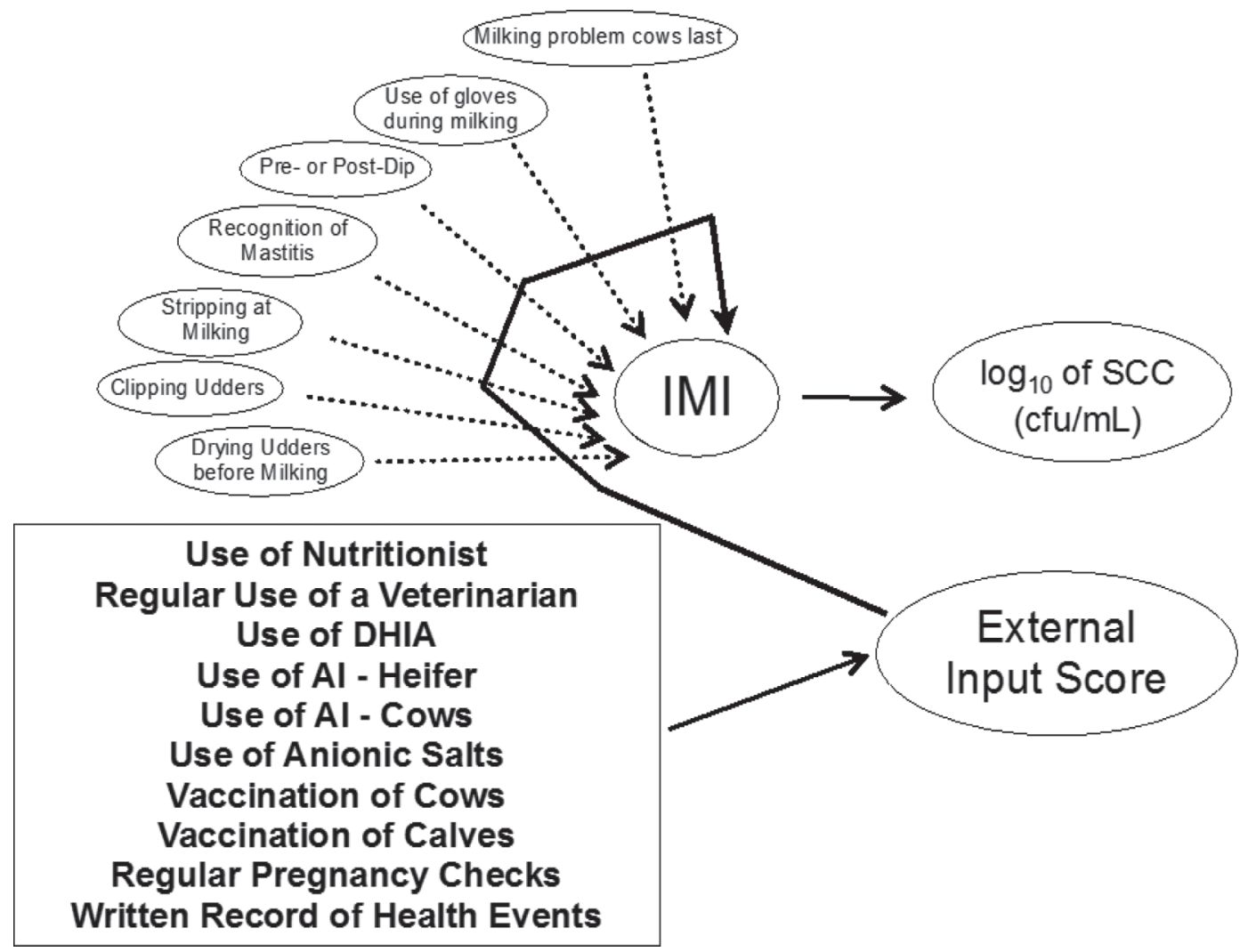

Figure 3. Relationship of external input score with IMI of dairy animals and the resulting SCC. The external input score is an additive score of several variables that indicate more involvement of outside sources in dairy farm management, which may be representative of the precision of various management procedures. Variables shown as being related to IMI by dotted arrows are representative of traditional variables used to troubleshoot IMI and increased SCC that were not significant in our modeling.

cant in our models. We postulate that many of these traditional variables are now less useful in reducing BMSCC, as many farmers are either already practicing these procedures, or know that this is an expected response. As described in Figure 3, we believe that the various EIS are indicative not only of how farmers use outside sources, but may also serve proxies for precision of the management procedures. Figure 4 indicates that a higher EIS was associated with CON management among size- and location-matched farms (simple regression; analysis not shown; $P<0.001$ ). This result supports the findings from Stiglbauer et al. (2013), which also showed that CON management was associated with more external resource use, but was assessed using a more limited external resource scale. Future research should include more specific questions aimed at outside management support used on the farm in order create a more complete picture of management on the farms and determine why the use of external resources was lower on organic farms.

Future studies that would allow investigators to follow farms over a longer period of time would be a useful way to build on the information we currently have available. Also, more demographics and farmer-attitude information should be gathered to provide a more complete picture with regard to the reasoning behind external resource use (or lack thereof). The research this manuscript suggests that external resource use by farmers may be an effective method of improving milk quality. This information could be used to enhance milk quality-improvement programs to maximize utility for the growing organic portion of the industry.

\section{CONCLUSIONS}

The increase in the demand for organic dairy products has produced the need for more knowledge and research on organic dairy management. Our research indicates that although each production system has unique challenges, the milk quality of organic and conventional dairy farms are not different. The LSCC of the population of all herds included in this study were most associated with the amount of grain fed, the presence of Staph. aureus in the bulk tank, the number of years in the dairy industry, and the EIS. The LSCC of the organic population of the study was influenced by 


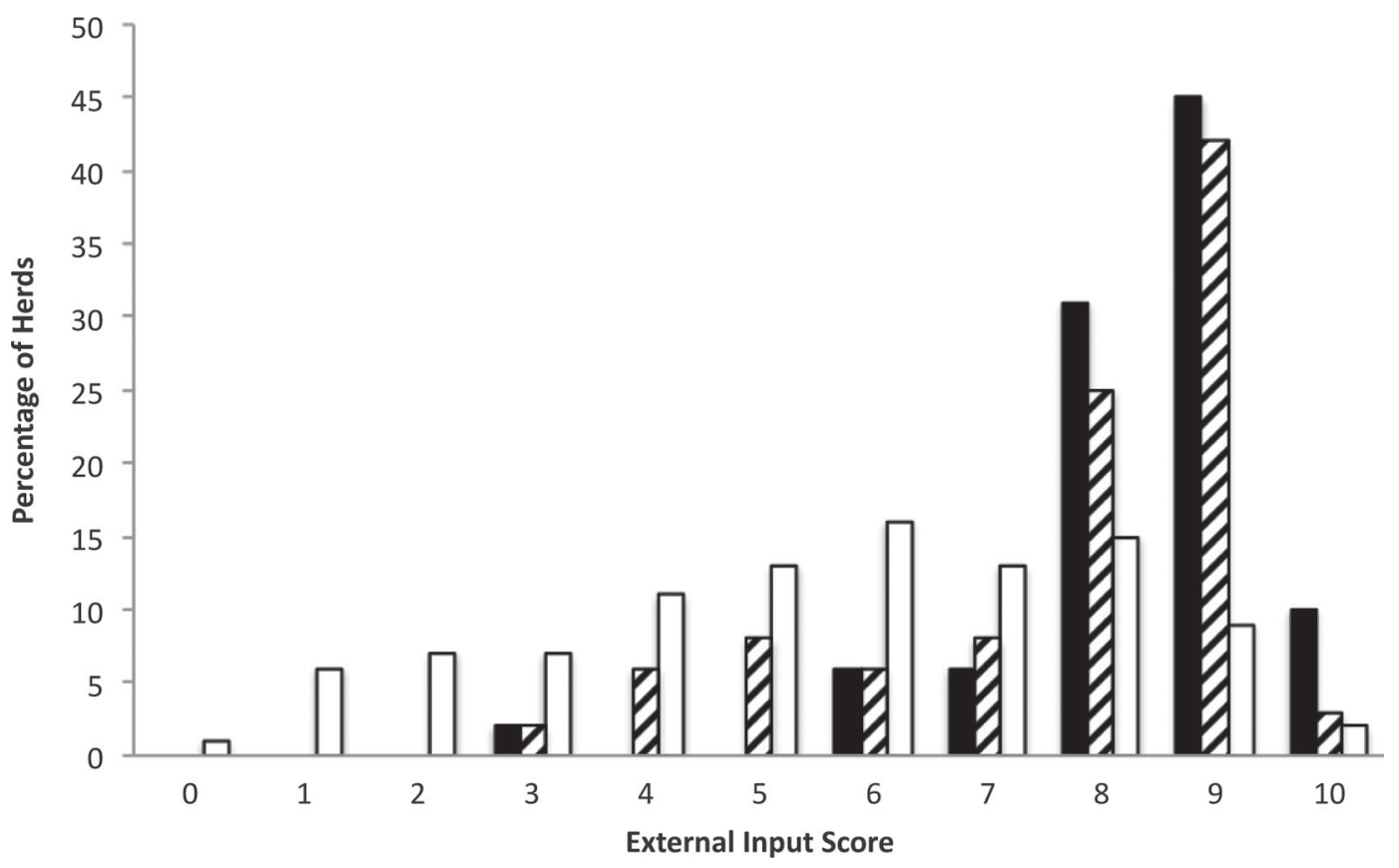

Figure 4. Percentage of dairy farms in each grazing system in New York, Oregon, and Wisconsin distributed by the external input score. Black bars represent conventional nongrazing farms $(\mathrm{n}=63)$, striped bars represent conventional grazing farms $(\mathrm{n}=36)$, and white bars represent organic farms $(n=191)$. The external input score is an additive score $(0$ to 10$)$ of several variables that indicate more involvement of outside sources in dairy farm management. The score consists of the following variables, using a 0 (no) or 1 (yes) scale: use of nutritionist (no or yes), regular use of a veterinarian (no or yes), use of DHIA (no or yes), use of anionic salts in transition-cow diets (no or yes), vaccination of cows (no or yes), vaccination of calves (no or yes), regular pregnancy checks (no or yes), a written record of herd health events (no or yes), any use of AI in nonlactating heifers (no or yes), and any use of AI in adult cows (no or yes). The overall finding was that organic farms use fewer external resources than their conventional counterparts $(P<0.001)$.

similar variables, with the exception of EIS. Other factors specific to the organic model included the use of a bucket milker at milking, the reported bulk tank SPC, the use of gloves during milking, the use of anionic salts in transition-cow diets, and a seasonal effect. The EIS offered an interesting analysis, as it provided insight into how the different grazing systems use external resources. Our analysis found that ORG farms were more likely to have a lower EIS than size- and locationmatched CON farms in this study. Further research should be done with the use of external management resources in mind, as well as to create a more exhaustive EIS scale.

\section{ACKNOWLEDGMENTS}

This study was supported by the US Department of Agriculture (USDA) National Institute of Food and Agriculture (NIFA) Integrated Organic Program, grant no. 2008-51106-19463, "Impact of Organic Management on Dairy Animal Health and Well-Being." We thank all the farms that participated in the study throughout New York, Vermont, Pennsylvania, Oregon, and Wisconsin. The authors also recognized the efforts of the laboratories at Quality Milk Production Services at
Cornell University (Ithaca, NY), Dairy One Cooperative Inc. (Ithaca, NY), and the University of WisconsinMadison Milk Quality Laboratory.

\section{REFERENCES}

Barkema, H. W., Y. H. Schukken, T. J. Lam, M. L. Beiboer, G. Benedictus, and A. Brand. 1998. Management practices associated with low, medium, and high somatic cell counts in bulk milk. J. Dairy Sci. 81:1917-1927.

Barkema, H. W., J. D. Van der Ploeg, Y. H. Schukken, T. J. G. M. Lam, G. Benedictus, and A. Brand. 1999. Management style and its association with bulk milk somatic cell count and incidence rate of clinical mastitis. J. Dairy Sci. 82:1655-1663.

Dohoo, I. R. 1982. Somatic cell counts in bovine milk. Can. Vet. J. $23: 119-125$.

Dohoo, I. R., W. Martin, and H. Stryhn. 2010. Veterinary Epidemiologic Research. 2nd ed. VER Inc., Charlottetown, PEI, Canada.

Dufour, S., A. Fréchette, H. W. Barkema, A. Mussell, and D. T. Scholl. 2011. Invited review: Effect of udder health management practices on herd somatic cell count. J. Dairy Sci. 94:563-579.

Elanco Animal Health. 1997. Body condition scoring in dairy cattle. Elanco Animal Health, Greenfield, IN.

Ferguson, J. D., D. T. Galligan, and N. Thomsen. 1994. Principal descriptors of body condition score in Holstein cows. J. Dairy Sci. 77:2695-2703.

Green, L. E., Y. H. Schukken, and M. J. Green. 2006. On distinguishing cause and consequence: Do high somatic cell counts lead to lower milk yield or does high milk yield lead to lower somatic cell count? Prev. Vet. Med. 76:74-89.

Hogan, J. S., R. N. González, R. J. Harmon, S. C. Nickerson, S. P. Oliver, J. W. Pankey, and K. L. Smith. 1999. Laboratory Hand- 
book on Bovine Mastitis. Rev. ed. National Mastitis Council Inc., Madison, WI.

Jothikumar, N., X. Wang, and M. W. Griffiths. 2003. Real-time multiplex SYBR green I-based PCR assay for simultaneous detection of Salmonella serovars and Listeria monocytogenes. J. Food Prot. 66:2141-2145.

Manning, S. D., R. T. Madera, W. Schneider, S. E. Dietrich, W. Khalife, W. Brown, T. S. Whittam, P. Somsel, and J. T. Rudrik. 2007. Surveillance for Shiga toxin-producing Escherichia coli, Michigan, 2001-2005. Emerg. Infect. Dis. 13:318-321.

Nam, H. M., V. Srinivasan, B. E. Gillespie, S. E. Murinda, and S. P. Oliver. 2005. Application of SYBR green real-time PCR assay for specific detection of Salmonella spp. in dairy farm environmental samples. Int. J. Food Microbiol. 102:161-171.

Olde Riekerink, R. G., H. W. Barkema, S. Veenstra, D. E. Poole, R. T. Dingwell, and G. P. Keefe. 2006. Prevalence of contagious mastitis pathogens in bulk tank milk in Prince Edward Island. Can. Vet. J. $47: 567-572$.

Pol, M., and P. L. Ruegg. 2007. Treatment practices and quantification of antimicrobial drug usage in conventional and organic dairy farms in Wisconsin. J. Dairy Sci. 90:249-261.

Reischl, U., M. T. Youssef, J. Kilwinski, N. Lehn, W. L. Zhang, H. Karch, and N. A. Strockbine. 2002. Real-time fluorescence PCR assays for detection and characterization of Shiga toxin, intimin, and enterohemolysin genes from Shiga toxin-producing Escherichia coli. J. Clin. Microbiol. 40:2555-2565.

Renshaw, R. W., R. Ray, and E. J. Dubovi. 2000. Comparison of virus isolation and reverse transcription polymerase chain reaction assay for detection of bovine viral diarrhea virus in bulk milk tank samples. J. Vet. Diagn. Invest. 12:184-186.

Richert, R. M., K. M. Cicconi, M. J. Gamroth, Y. H. Schukken, K E. Stiglbauer, and P. L. Ruegg. The role of the veterinarian on organic and conventional dairy farms. J. Am. Vet. Med. Assoc. In press.

Roesch, M., M. G. Doherr, W. Schären, M. Schällibaum, and J. W. Blum. 2007. Subclinical mastitis in dairy cows in Swiss organic and conventional production systems. J. Dairy Res. 74:86-92.

Rosati, A., and A. Aumaitre. 2004. Organic dairy farming in Europe. Livest. Prod. Sci. 90:41-51.

Ruegg, P. L. 2009. Management of mastitis on organic and conventional dairy farms. J. Anim. Sci. 87:43-55.

SAS Institute. 2008. SAS $/$ STAT $^{\circledR} 9.2$ User's Guide. SAS Institute Inc., Cary, NC.

Sato, K., P. Bartlett, R. Erskine, and J. Kaneene. 2005. A comparison of production and management between Wisconsin organic and conventional dairy herds. Livest. Prod. Sci. 93:105-115.

Sato, K., T. W. Bennedsgaard, P. C. Bartlett, R. J. Erskine, and J. B. Kaneene. 2004. Comparison of antimicrobial susceptibility of Staphylococcus aureus isolated from bulk tank milk in organic and conventional dairy herds in the Midwestern United States and Denmark. J. Food Prot. 67:1104-1110.
Schreiner, D. A., and P. L. Ruegg. 2003. Relationship between udder and leg hygiene scores and subclinical mastitis. J. Dairy Sci. 86:3460-3465.

Schukken, Y. H., D. J. Wilson, F. Welcome, L. Garrison-Tikofsky, and R. N. Gonzalez. 2003. Monitoring udder health and milk quality using somatic cell counts. Vet. Res. 34:579-596.

Smith-Spangler, C., M. L. Brandeau, G. E. Hunter, J. C. Bavinger, M. Pearson, P. J. Eschbach, V. Sundaram, H. Liu, P. Schirmer, C. Stave, I. Olkin, and D. M. Bravata. 2012. Are organic foods safer or healthier than conventional alternatives? A systematic review. Ann. Intern. Med. 157:348-366.

Sol, J., and O.C. Sampimon. 1995. Dry cow treatment with $600 \mathrm{mg}$ dynomilled cloxacillin or $250 \mathrm{mg}$ cephalonium: Comparison of cure rate, new intramammary infection rate and somatic cell count. Pages 146-147 in Proc. Natl. Mastitis Council Annu. Mtg. National Mastitis Council, Verona, WI.

Stiglbauer, K. E., K. M. Cicconi-Hogan, R. Richert, P. L. Ruegg, Y. H. Schukken, and M. Gamroth. 2013. Assessment of herd management on organic and conventional dairy farms in the United States. J. Dairy Sci. 96:1290-1300.

Sundrum, A. 2001. Organic livestock farming. Livest. Prod. Sci. $67: 207-215$.

USDA AMS (US Department of Agriculture Agricultural Marketing Service). 2007. National Organic Program. Accessed Sep. 1, 2012 http://www.ams.usda.gov/AMSv1.0/nop.

USDA ERS (US Department of Agriculture Economic Research Service). 2008. Organic production. Accessed Sep. 1, 2012. http:// www.ers.usda.gov/Data/Organic/.

Van Kessel, J. A. S., J. S. Karns, J. E. Lombard, and C. A. Kopral. 2011. Prevalence of Salmonella enterica, Listeria monocytogenes, and Escherichia coli virulence factors in bulk tank milk and in-line filters from U.S. dairies. J. Food Prot. 74:759-768.

van Schaik, G., M. Lotem, and Y. H. Schukken. 2002. Trends in somatic cell counts, bacterial counts and antibiotic residue violations in New York State during 1999-2000. J. Dairy Sci. 85:782-789.

Wehr, M., and J. Frank. 2004. Standard Methods for the Examination of Dairy Products. 17th ed. American Public Health Association, Washington, DC

Wilson, D. J., R. N. Gonzalez, and P. M. Sears. 1995. Segregation or use of separate milking units for cows infected with Staphylococcus aureus: Effects on prevalence of infection and bulk tank somatic cell count. J. Dairy Sci. 78:2083-2085.

Yiridoe, E., S. Bonti-Ankomah, and R. C. Martin. 2005. Comparison of consumer perceptions and preference toward organic versus conventionally produced foods: A review and update of the literature. Renew. Agric. Food Syst. 20:193-205.

Zwald, A. G., P. L. Ruegg, J. B. Kaneene, L. D. Warnick, S. J. Wells, C. Fossler, and L. W. Halbert. 2004. Management practices and reported antimicrobial usage on conventional and organic dairy farms. J. Dairy Sci. 87:191-201. 